\title{
Transnational Migration Law: Authority, Contestation, Decolonization a
}

Sara Dehm

The Oxford Handbook of Transnational Law

Edited by Peer Zumbansen

Subject: Law, International Law, Law and Society, Legal System, Comparative Law

Online Publication Date: Apr 2021 DOI: 10.1093/oxfordhb/9780197547410.013.31

\section{Abstract and Keywords}

This chapter trace how "transnational migration law" has come to construct human mobility. It argues that transnational migration law is best conceived of as a useful methodological approach, rather than a distinct area of legal doctrine or spatial domain of law. Conceived as a method, transnational migration law can reveal the juridical assemblage of practices, subjects, and relations for regulating migration. This chapter illuminates some of the core and potentially rival sites, forms, and practices of transnational migration lawmaking, drawing attention to the productive and coercive forces of transnational migration law that have resulted in the maintenance of a "global hierarchy of mobility." Yet, recognizing that state attempts to monopolize "the legitimate means of movement" are incomplete and contested, the chapter argues that scholars of "transnational migration law" must pay attention to diverse and situated Indigenous legal traditions as sources of authority. In doing so, the chapter critically unpacks the relationship between migration and struggles for decolonization and global justice.

Keywords: migration, human mobility, plural authority, state violence, global justice, Indigenous sovereignty

\section{Introduction}

ON July 20, 2015, the Haudenosaunee Nation Women's Lacrosse Under-19 team, the Haudenosaunee Nationals, announced that they would no longer be competing in the World Championships scheduled to begin a few days later in Edinburgh, Scotland. The reason for their withdrawal was the persistent refusal of UK immigration officials to recognize the team members' Haudenosaunee passports for the purpose of entering the United Kingdom. ${ }^{1}$ This refusal had previously sparked a diplomatic standoff in 2000 , when the Iroquois Nationals men's squad was unable to travel to compete in a world tournament held in Manchester, England, for a similar reason. Yet, after much political efforts on the part of Haudenosaunee diplomats, two years later, the Haudenosaunee Nationals would play in the 2017 World Championship held in Guildford, England, having arrived in the 


\section{Transnational Migration Law: Authority, Contestation, Decolonization}

United Kingdom on their Haudenosaunee passports. ${ }^{2}$ In the words of the Haudenosaunee women's (p. 684) team captain Amber Hill, this was an important moment that represented an "acknowledgment of the Haudenosaunee as our own sovereign people." 3

This chapter suggests that the struggle over the recognition of the Haudenosaunee passport can be read as a story about transnational migration law. Rather than simply a matter of conflicting jurisdictions, overlapping sovereignties or the lawfulness of a particular document, it also denotes a fundamental struggle over the very recognition and definition of a lawful authority and the power to authorize lawful movement at the start of the twenty-first century. In the context of migration, such legal struggles occur between a plethora of potentially "rival" authorities seeking to bring the regulation of mobile people into their jurisdiction. ${ }^{4}$ In this chapter, I seek to capture such struggles through describing and theorizing "transnational migration law." Here, I understand "transnational migration law" to be a juridical assemblage of practices, subjects, and relations that become visible through a particular analytics that refracts questions of legal authority and lawful relations through the concept of the "transnational." In short, this means transnational migration law is not a specific preexisting field of law, or readily-accessible object of study, but rather must necessarily be constructed into a recognized area of legal inquiry, engagement, and analysis.

My argument is that transnational migration law is best conceived of as the product of a mode of scholarly engagement and critique concerning the regulation of human mobility that is facilitated through an attentiveness to the idiom of the "transnational." Following Zumbansen, the idiom of the "transnational" is less a spatial domain than a useful methodological approach that, in the context of international migration, can reveal how human mobility has come to be governed, ordered, and contested in the contemporary world. ${ }^{5}$ The idiom of the "transnational" thus offers a lens for analyzing and denaturalizing the international system of nation-states in the present, and helps us to understand how modern states-as powerful political institutions that purport to monopolize the "legitimate means of movement" 6 - have been made, enacted, and challenged by a range of actors, processes, and collectives, within and beyond the nation.

This chapter consists of two sections. In section II, I unpack the idiom of the "transnational" in relation to migration (and) law, and then proceed to map a range of practices enacted by different, at times rival, authorities in the contemporary world. While it would be impossible to adequately touch upon the diversity of public and private actors that give (p. 685) shape to the transnational regulation of migration, what I hope to illuminate are some core contested sites, forms, and practices of legality that these actors have come to create and use in the regulation of human mobility. Here in particular, I draw attention to the technologies of control, differentiation, and selection that have come to characterize much of transnational migration law. Taken together, these practices and technologies constitute the productive and coercive forces of transnational migration law. In section III, I argue that scholars of transnational migration law need to think critically about the relationship between migration and struggles for decolonization and global justice. In settler-colonial contexts, this means holding on to an antiracist politics that challenges state 
law's logics and practices of stratification, selection, elimination, and exclusion, while also centering diverse and situated Indigenous legal traditions as sources of authority in the making of migration laws. ${ }^{7}$ Furthermore, attending to the relationship between the multitude of struggles for migrant justice around the world and situated projects of decolonization is all the more pressing in light of the increasing technologies of control, containment, surveillance, and segregation that states are employing in their regulation of human mobility at the start of the twenty-first century. Such technologies have resulted in the maintenance of a "global hierarchy of mobility" - or what some scholars have called "global apartheid" - that allows the global elite to travel with security, resources, and ease while other racialized migrants, primarily poorer people of color from the Global South, may only be able to travel in limited, bonded, precarious, unauthorized, or dangerous ways. ${ }^{8}$

\section{Conceptualizing Transnational Migration Law}

\section{A. Key Concepts}

The term "transnational migration law" requires some probing. It is, after all, a term that can be located in different scholarly traditions of thinking about human relations outside of and beyond the state, most notably in legal scholarship that position an analytics of "transnational law" against mid-twentieth-century formalist accounts of international law. ${ }^{9}$ The (p. 686) concept of "migration" also, as distinct from terms such as "travel," "colonization," "movement," or "resettlement," has particular connotations. For this reason, each element of the term "transnational migration law" needs unpacking. What does it mean to speak of something as "transnational" (whether it be a phenomenon, a subject of legal regulation, a legal domain, or an approach to law)? How might we understand "migration" as an object of study? And what is at stake in our accounts of law as transnational in conceptualizing the regulation of "migration"? To respond to these broad questions, I consider each element of the term "transnational migration law" in turn.

First, transnational: I argue that the idiom of the transnational offers a critical viewpoint for, first, showing the limits of how conventional accounts of migration law in both their domestic and international guises are understood and for, second, offering a reconstructed understanding of how human mobility is governed in our contemporary world. This latter reconstructive gesture allows for capturing legal relations that extend beyond and constitute the territorial space of the "national" such that they might be thought of as creating a particular legal domain-that of transnational migration law-differently. Put otherwise, this chapter uses the analytics of "transnational" not as a spatial term that seeks to overcome or unsettle the tired binary between the domestic and international. This means that the transnational is not a subcategory of scale structured through a logics of verticality where the "transnational" ambivalently sits somewhere between the "global" and the "local." Rather, the idiom of the "transnational" offers what might be 


\section{Transnational Migration Law: Authority, Contestation, Decolonization}

best thought of as a diagnostic from which to mount a critique of existing ways of framing "migration law" as well as for refiguring legal relations. In this latter sense, it offers an analytics of relations: that is, a transnational approach allows us to make visible the production, enactment, and maintenance of particular sets of structural relations and the enactment of an assemblage of legal practices that shape how people move in the contemporary world. ${ }^{10}$ In the context of migration, this can mean looking to the regulatory power and effects of transnational structures of capitalism and neoliberal globalization alongside the complex set of migrant networks that span across different cities in different states for an account of the legal regulation of human mobility. Yet, in referencing the "national," the term transnational also risks recentering the state in the discussion, naturalizing the state as a stable historical actor and political concept despite the fact that the emergence and maintenance of the state as a principal political authority has been a recent historical phenomenon and one that must be constantly enacted, reimagined, and held together through a variety of institutional techniques and practices.

Next, migration: I understand human mobility to be the capacity of people to move across space and their physical acts of movement, including moving in-between and across spaces marked by different and potentially rival political authorities. In contrast, I take migration to refer to specific forms of human mobility that are shaped through law and regulation. To speak of migration is then to always already reference the product of particular legal and institutional arrangements that determine or channel how people can and do move, and how that movement is understood, enabled and authorized (or not, as in the case of illegalised or clandestine migration). In the contemporary world, this means recognizing that references to the term "migration"-either as "internal" or "international"-rely upon the existence of the state as the dominant and purportedly universalized container that structures (p. 687) ideas of human life, sociality, and belonging, and has become an assumed referent in our understandings of human mobility. Holding on to the distinction then between human mobility and migration importantly allows for questioning how different forms of human mobility come to be framed, conditioned, and channeled through historically specific political institutions (such as the state) and the associated regimes of migration law and regulation that these institutions have enabled and protected. This includes noticing the assemblage of terminologies, techniques, and norms for controlling or channeling human mobility that have made mobility across state borders "not equally accessible for all."11 Distinguishing between "migration" and "human mobility" also allows for thinking critically about the regulation of human mobility through the categories offered by either international or domestic law such as "economic migrant," "illegal immigrant," "refugees," "trade in services," "family reunification," or "citizen." Or to put it more fundamentally, it allows for a recognition that the very categorization of a person as a "migrant" or "citizen" also already rests upon a prior recognition of a set of legal institutions, techniques, and categories that structure our understanding of the particular relation between a person and the space that they inhabit or move in. By extension, to refer to "migration law" then frequently takes for granted the way that human mobility may be shaped through institutional regimes, most notably through assuming the presence of the state as the main container for authorizing and regulating human 


\section{Transnational Migration Law: Authority, Contestation, Decolonization}

mobility. Or, as Catherine Dauvergne has put it, "without immigration law there is no such thing as illegal migration."12

And finally, law: here, rather than setting out a precise definition of law, I adopt an orientation toward thinking about law through questions of its authorization, mechanics, and contestations-as well as the prior question of recognition. What forms of political authority are recognized as lawful? Through what modes of representation are forms of law authorized or enacted? How do different forms of law encounter or relate to each other? This means that instead of enumerating the doctrines and sources of transnational migration law, I am instead interested in attending to struggles over the authority to regulate human mobility that involve, exceed and displace the modern state as the only perceived source or form of "proper" law in the world. ${ }^{13}$ This might be best thought of as a project of critically redescribing the world through an attentiveness to plural legal authorities and practices of law that order relations between mobile people and political authorities in specific times and places. ${ }^{14}$ It also (p. 688) involves a recognition of state law as the active agent in processes of illegalization, that is, in "making people illegal."15

How then has human mobility come to be regulated at the turn of the twenty-first century? In this new millennium, it has become commonplace to say that we live in a world of human mobility. The 2017 UN Secretary-General Report, entitled Making Migration Work for All, for instance, began by noting that migration is an "an expanding global reality," a phenomenon that represents "one of the most urgent and profound tests of international cooperation in our time." 16 This language of urgency and crisis is habitually reiterated, including in official state discourses, institutional documents, and media representations. We need only think of a few recent examples to suffice: the "global refugee crisis," the "2014 Central American-US migration crisis," the "European migration crisis of 2015," and so forth. Similarly, migration law itself-in both its domestic and international guises -is also commonly depicted through the language of crisis. ${ }^{17}$ State immigration laws, in such depictions, are said to be threatened by the mass displacement or influx of people into a particular state, or failing the community of citizens who implemented them (by, for example, offering "too many" rights and benefits to noncitizens) such that it is deemed to be in need of reform or renewal. This language of "crisis" reflects what sociologist Zygmunt Bauman has termed "migration panic," referring to rhetorical discourses that are directed toward infusing a sense of fear and vulnerability in migrant-receiving societies. ${ }^{18}$ Rather than illuminating the forces of global capitalism and economic liberalization that may compel migrants from states experiencing the ongoing legacies of colonization, political conflicts and economic turmoil to move, discourses of moral panic instead target migrants to make them into "collateral victims" of migrant receiving states' anxieties and insecurities.

Additionally, the dual framings of these "crises" of human mobility and of law assume a particular state of normalcy where people can and should move in a certain, consistent ways and state law can and should control migration, thus maintaining an illusion and project of control over mobile people for the state. It also obscures the fact that the overwhelming number of people in the world remains sedentary, either by choice or by cir- 


\section{Transnational Migration Law: Authority, Contestation, Decolonization}

cumstance. While the number of people globally classified as "migrants" has grown in recent years, migrants still only constitute around 3.4 percent of the world's population, even if this percentage-as is stated in the UN Secretary-General's report-amounts to an estimated 258 million people. In adopting a critical distance to this language of "crisis," this chapter instead seeks to uncover how control over human mobility is itself a struggle between different and at times rival political authorities. To do so, in the next subsection, I turn to the more mundane and everyday modes of regulating human mobility that, despite-or perhaps even more accurately, owing to-their "normalcy" or technicality, can still have severe (p. 689) effects and consequences for people who migrate in ways that may be unauthorized by states or that led to the production of deportability, regimes of racial exclusion or lives of precarious and exploitable existence.

\section{B. Mapping the Plural and Contested Actors, Sites, and Modes of Transnational Migration Lawmaking}

In this section, I posit that giving an account of transnational migration law means making visible plural and contested sites and modes of regulation, actors of lawmaking, and forms of authority and legal subjects and relations of control over mobile people. This project of recognition and mapping can then facilitate foregrounding the effects of transnational migration law in positioning certain people as racialized, precarious, and deportable "migrants" who are not entitled to the same legal protections and forms of social belonging as those people recognized as "citizens." 19 Analytically, such exercises in describing transnational migration law as a constituted field of legal inquiry, engagement, and analysis allows us to see what I shall refer to as both the productive and coercive forces at work in this domain. That is, how particular sites, subjects, and forms of legal authority are produced, assembled and regulated (productive forces), and the effects of that regulation in creating new hierarchies, forms of power/exploitation, and political contestations and possibilities (coercive forces). This acknowledgment of the productive and coercive forces of transnational migration law needs to be tempered with a recognition that the state's purported monopoly over the "legitimate means of movement" has never been, and can never be, fully realized in the face of migrants who travel clandestinely in defiance of state borders and, in the context of settler colonial states, Indigenous nations who maintain their sovereignty over land and people.

As a starting point, a politically informed and empirically accurate account of transnational migration law should recognize "migrants" as law-creating actors who are involved in shaping, negotiating, and resisting spaces of regulation within and beyond the state. For instance, this can entail noticing how regimes of migration control are necessarily responsive to the very movement and action of mobile people and how the decision-making of migrants and the routes that they choose to migrate along "can force the reorganisation of control itself." ${ }^{20}$ For instance, in recent years, migrant use of technologies such as mobile phones along popular routes of mass migration has allowed migrants to increase their access to information, to initiate rescue operations, and to articulate new sets of rights claims in law (such as the right to a mobile phone), while also informing and transforming (p. 690) how state and other authorities use digital tracking and surveillance to 


\section{Transnational Migration Law: Authority, Contestation, Decolonization}

monitor and control unauthorized movement. ${ }^{21}$ Additionally, centering the lawmaking action of migrants can mean acknowledging migrants as part of local or transnational civil society coalitions that create "alternative political spaces to the 'official' fora" of transnational migration governance while nonetheless still recognizing them as, what Stefan Rother has called, "transnationally marginalized groups." 22 The "Civil Society Days" as part of the Global Forum on Migration and Development provide one such example of a space and platform from which migrants can articulate regulatory proposals and demands. ${ }^{23}$ Another good example of such latter forms of regulation is the Coalition of Immokalee Workers (CIW)'s Fair Food Program that has improved the conditions of migrant farmer workers in the tomato industry in Florida and other eastern coast states in the United States. The program adopts a variety of mechanisms for regulating the industry supply chain including legally binding agreements with large-scale buyers and consumer education campaigns. These mechanisms are largely worker-driven and workercertified, and center around a Code of Conduct that covers key areas of workers' rights and protections (including wages, occupational health and safety, antidiscrimination, etc.). ${ }^{24}$ While the program does not address the regulation of migrant admissions or status in the United States (what might be considered the "traditional" doctrinal area of immigration law), it does affect what gets recognized as the "proper" working conditions of certain migrant farmer workers and their enforceability in practice. It is thus one instance of migrant worker lawmaking, standard-setting, and enforcement that forms part of the assemblage of norms, practices, actors and processes that make up transnational migration law.

Undoubtedly, states have become central actors in channeling and controlling migration. State institutions can and routinely do enact immigration laws, administer visa regimes, police the immigration status of individuals in their territories, and deport people deemed to be noncitizens without entitlement to remain within the espoused territory of the particular state. In this way, states have attempted to assert a principal monopoly over how state-based regime of nationality and/or citizenship operate, dictating not only the formal rights, privileges, and access to resources of individuals within a state's territory but also affecting how this bestowal of status is recognized by other states too. After all, a person's recognized nationality is a significant determinant of their ability to access state documentation that can facilitate authorized and safe travel to other states, with different state passports treated vastly differently by state authorities. While this emergent global hierarchy of passports (p. 691) allows some "privileged" travelers-primarily individuals from economically powerful states, often in the Global North-to migrate with little consideration of state and regional visa regimes, for others it can result in stasis due to discriminatory visa regulations and restrictions elsewhere. ${ }^{25}$

Yet, an attentiveness to different forms of legal authority entails disaggregating the state as an actor to understand how bodies within a state may act in at times contradictory ways in the regulation of migration, or indeed, how different states approach regulating human mobility. ${ }^{26}$ For example, while state immigration authorities may act to select, filter, and/or exclude potential and actual migrants from a state's territory, state employment law enforcement bodies may act to recognize migrants as legal subjects with partic-

Page 7 of 28

PRINTED FROM OXFORD HANDBOOKS ONLINE (www.oxfordhandbooks.com). (C) Oxford University Press, 2018. All Rights Reserved. Under the terms of the licence agreement, an individual user may print out a PDF of a single chapter of a title in Oxford Handbooks Online for personal use (for details see Privacy Policy and Legal Notice). 
ular entitlements irrespective of their migration status, including people who may no longer be physically present in the territory of a state. In South Africa, for instance, the Commission for Conciliation, Mediation and Arbitration (CCMA) has since 2008 recognized that migrants working in South Africa "illegally" - that is without state authorization or documentation-are entitled under the South African Constitution to the protections of South African labor laws and standards, including against unfair dismissal. This recognition has had the effect of bringing the regulation of unauthorized migrant workers outside of a purely immigration enforcement jurisdiction and into a much broader purview of state institutions. ${ }^{27}$ While this formal development is significant, in practice, many migrant workers still appear to be reluctant to access such protections for fear of deportation by the state or retribution from their employers. ${ }^{28}$

Such instances of state lawmaking and rearrangements of jurisdiction might extend certain aspects of labor law protection; yet they nonetheless remain limited in addressing the underlying economic and social dynamics that compel migrant workers to accept jobs with limited rights and remunerations, or indeed, state impositions of the fundamental distinction between citizens/noncitizens. In Canada, for example, the Ontario Workplace Safety and Insurance Appeals Tribunal decided in 2017 that a migrant worker from Jamaica, Michael Campbell, was entitled to partial-loss-of-earning benefits after he sustained a back injury while working on a fruit farm as part of Canada's Seasonal Agricultural Workers Program (SAWP). ${ }^{29}$ A key consideration in the case was whether the quantum of the man's entitlement should be assessed with reference to a suitable occupation available to him in Canada or in his home state of Jamaica. In deciding the latter, the ruling overturned an earlier Workplace Safety and Insurance Board decision to cut Campbell's entitlements on the basis that he could find alternative work as a cashier in Ontario, despite the fact that Campbell had long since returned to live in rural Jamaica and had no entitlement to return (p.692) to Canada. While the ruling provides an important benchmark for subsequent compensation claims by injured migrant workers who are working or have worked in Canada, it ultimately remains unable to challenge how the SAWP's specific mode of production and profitability rests of the creation and supply of an unfree, deportable, racialized, and precarious labor force that may place them at greater risk of particular work place injuries. ${ }^{30}$

Alongside this attentiveness to such varied forms of state regulation, transnational migration law also encompasses the growing raft of international norms, conventions, processes, and others instruments that have come to challenge, complicate, or interact with state attempts to monopolize the "legitimate means of movement." 31 Here key instruments directly addressing migrant rights or criminalizing certain forms of violence against migrants include the UN Convention on the Rights of All Migrant Workers and Their Families (1990), the Protocol against the Smuggling of Migrants by Land, Sea and Air (2000), and the Protocol to Prevent, Suppress and Punish Trafficking in Persons (2000). Yet, a multitude of other instruments and processes covering discrete aspects of human mobility in the fields of trade, labor, human rights, maritime and air law, consular and diplomatic protection, and nationality law also add to this expanding yet fragmented international jurisdiction. While these instruments might "converge" with or "diverge" from each other 


\section{Transnational Migration Law: Authority, Contestation, Decolonization}

in terms of their norms, processes, and substance, depending on specific regime interactions, in general, they cohere around a dominant understanding of sovereignty that allows states to exclude non-nationals as a state sees fit and places no duty of admission on states (with only minor exceptions most notably for humanitarian reasons in the context of refugee law or for the protection of life under the law of the sea). ${ }^{32}$ Nonetheless, asserting and determining the jurisdiction of a particular international instrument can affect the obligations and conduct of states toward migrants once they have been lawfully admitted into their territories.

Regional interstate bodies too have become contested sites for the adjudication and regulation of migrant standards that can challenge a state's distribution and restriction of entry, rights and resources. These regional authorities have given particular substance to how key norms within international instruments should be interpreted and applied, and have provided key sites for scrutinizing state conduct and, at times, advancing migrant rights. The African Commission on Human and People's Rights, for instance, has held that state authorities should not deport an individual without "giving them the possibility to plead their case before the competent national courts," irrespective of their immigration status. ${ }^{33}$ To take another similar example from a different regional context: in 2003, the Inter-American Court of Human Rights (IACrtHR) issued an important advisory opinion on the rights of undocumented migrants, at the request of Mexico who was motivated by the treatment of Mexican nationals in the United States. The Court's Advisory Opinion emphasized that all states are required to respect and protect the principles of nondiscrimination and equality of individuals before the law as a jus cogens norm of international law, including in (p. 693) relation to the treatment of migrants and noncitizens. Critically, the Court stated the "migratory status of a person can never be a justification for depriving him [sic] of the enjoyment and exercise of his [sic] human rights, including those related to employment." 34

More recently, in 2016, an Inter-American Commission on Human Rights (IAComHR) decision found that the United States had violated the rights of undocumented workers by failing to provide them with Social Security benefits and equal treatment before the law. ${ }^{35}$ The case concerned two Mexican nationals, Leopoldo Zumaya and Francisco Berumen Lizalde, who had both been injured while working in the United States, the former man as an apple picker and the latter man as a painter. Both the IAComHR decision and the Mexican request of the IACrtHR Advisory Opinion were in response to an earlier 2002 US Supreme Court decision of Hoffman Plastic Compounds that had held that an undocumented worker who had been illegally fired by her employer was not entitled to recover unpaid wages nor any lost earnings. ${ }^{36}$ Through its decision that included several recommendations for US domestic law reform, the IAComHR positioned itself as the proper authority for determining the rightful distribution of rights and resources within its member states including to people present within a political community without state authorization. In response, the US expressed "disappointment" in the Commission's rejection of the United States' argument that the case was inadmissible on the basis of time restrictions, and noted that it "strongly disagreed" with the Commission's finding that the United States had "any international legal obligations" in regards to the matter. ${ }^{37}$ Scholars 


\section{Transnational Migration Law: Authority, Contestation, Decolonization}

have noted that the Inter-American human rights institutions-as new sites of struggle over migrant rights-have demonstrated a "remarkable" willingness to place "human beings at the centre" of their jurisprudence, ${ }^{38}$ even if their actions have not necessarily "brought about clear improvements in the treatment of migrant workers in the region." 39

Yet the effect of such political, economic, and judicial institutional regionalization of the regulation of human mobility is paradoxical: oscillating between enabling new forms of contestation, on the one hand, and new modes of norm harmonization in line with state conduct, on the other. This means that while some actions of regional institutions do challenge states' ability to exclusively determine the rights and conditions of migrants in their territories, other regional initiatives act to bolster and rationalize the authority of a state to manifest more exclusive control over human mobility at and within its borders. For example, since 2006, the African Union has had a Migration Policy Framework for Africa that reiterates principles of state sovereignty while providing member states with "comprehensive policy guidelines and principles" in a range of areas (labor migration, border governance, irregular migration, forced displacement, etc.) to assist in the development of each state's migration, custom, labor, (p. 694) trade, and other laws. ${ }^{40}$ The AU also has an African Union Labour Migration Advisory Committee, whose mandate is to facilitate, monitor, and report on the implementation of AU migrant worker standards in the region. While these instruments might best be considered "soft law," they can still be instructive in shaping the behavior of states in their treatment of migrants. Understanding transnational migration law then requires an attentiveness not only to the developments, technicalities, and impacts of these regional regimes but also to the "interplay" between different forms of regionalism vis-à-vis international institutions, domestic law, civil society actors, and migrants themselves. ${ }^{41}$

Alongside such dynamics of regionalization, a multitude of other private and quasi-private actors have come to be enrolled in the facilitation and regulation of international migration, creating new relationships of both antagonism and exploitation on the one hand, and dependency and profit on the other. On the recruitment side of labor migration, the role of labor brokers in states of origin has transformed from being mere facilitators of migration to acting as key drivers of the migration process as so-called "merchants of labour." 42 It is estimated that there are now thousands of small licensed migrant worker recruitment agencies located in capital cities across Asia in addition to unlicensed recruiters. ${ }^{43}$ The actions of these labor brokers can not only profoundly shape the experiences, opportunities, decisions, and vulnerabilities of migrant workers but also come to create the normative landscape in which migrant workers move, act, and live. During the process of travel too, carrier sanction laws and civil aviation practices shape the conduct of commercial airlines and place penalties (including hefty fines) on a carrier who allows a person to travel without the required documentation or fails to enforce the visa requirements of the destination state. Private companies are thus enrolled in the immigration infrastructure of a state, acting as de facto enforcers of a state's immigration screening rules and processes beyond the state's actual territory. ${ }^{44}$ And within a migrant's state of employment, their private employers also become actors with authority, in some cases even called upon by state institutions to police immigration status and control migrants' expe-

Page 10 of 28

PRINTED FROM OXFORD HANDBOOKS ONLINE (www.oxfordhandbooks.com). (c) Oxford University Press, 2018. All Rights Reserved. Under the terms of the licence agreement, an individual user may print out a PDF of a single chapter of a title in Oxford Handbooks Online for personal use (for details see Privacy Policy and Legal Notice). 


\section{Transnational Migration Law: Authority, Contestation, Decolonization}

riences of employment. While some initiatives such as the Dhaka Principles for Migration with Dignity, finalized by the Institute for Human Rights and Business in 2012, adopt a sector-wide approach to regulating this diffused set of actors in the migrant labor recruitment supply chain, such initiatives remain largely at the margins of other state-championed practices. ${ }^{45}$

(p. 695) Finally, transnational migration law should also take into account the laws and practices of Indigenous nations across the world that also regulate migration, even if their laws and authority to do so are not always recognized by state institutions or other actors. For example, in settler colonial contexts, this can mean recognizing that Indigenous nations do as a matter of both fact and law exercise authority over their lands and the people residing and visiting there, using a variety of jurisdictional techniques and practices such as: enacting ceremonial welcomes; issuing, use, and recognition of First Nations passports; maintaining communal membership practices; practicing oral traditions of storytelling; adhering to Indigenous protocols for visiting places; and traveling along recognized travel routes. ${ }^{46}$ As I will discuss in the final section of this chapter, migration law scholars have a responsibility to acknowledge and foreground such practices as a form of sovereign lawmaking so as to not perpetuate the logic of settler colonialism, including the durability of the terra nullius doctrine, in our scholarship and academic praxis. ${ }^{47}$

\section{Tracing Forms of Transnational Migration Law}

Alongside these different sites, actors, and subjects of regulation, new transnational modes of regulation have emerged that shape how the relationship between authority and mobile people are constructed and governed. These include, but are not limited to, what I shall call the technologization, privatization, and securitization of transnational migration law. To illustrate, I elaborate briefly on each of these forms of regulation in the following, focusing in particular on how these forms increasingly mediate the relationship between the state as a dominant actor of regulating migration and the mobile person. In doing so, these regulatory modes not only change the patterns and practices of migration, but also transform understandings and practices of modern statecraft.

Technologization: It is almost trite to state that technology is rapidly reshaping the practices and forms of the transnational regulation of migration. From biometric passports to mobile phones to complex data management systems at state borders, technology has transformed the modes through which state institutions assert their control over mobile people as well as how migrants themselves might resist and subvert such practices of control. Stephan Scheel argues that while the "digitisation and datafication of border control practices" should be seen as the "continuation and refinement" of earlier practices of controlling and sorting potential migrants through visa regimes that operate within and beyond a state's borders, he argues that it also important to account for "technological imperfections of biometric recognition systems, the trade-offs implicated in their implementation, the painstaking work it requires to make them work, the discretion of border control authorities on the ground and, most crucially, the capacity of those whose mobili- 


\section{Transnational Migration Law: Authority, Contestation, Decolonization}

ty they serve to control to compromise and circumvent biometric recognition systems." 48 Technological (p. 696) systems then are yet another site at which the contestations over migration control play out. Yet the technologization of migration law also provides possibilities for forms of increased accountability, with, for instance, certain so-called "migrant-sending" states using technology to seek to increase the effective operation of migrant worker rights. Since 2016, for example, Pakistani migrant workers have been able to lodge complaints via an online system about their recruitment and employment to the Pakistani Ministry of Overseas Pakistanis and Human Development, thereby increasing the reach of the Pakistani state but also changing practices of diplomatic protection, governmental responsibility and diaspora engagement. ${ }^{49}$ The potential and effectiveness of such technological forms of accountability for addressing and remedying migrant worker exploitation remain underexamined.

Privatization: The enrolment of private for-profit nonstate actors in the regulation and control of human mobility has resulted in the outsourcing of state responsibility and diffusion of accountability for the regulation and control of mobile people. For example, the rise of immigration detention for people arriving without state authorization or overstaying and/or breaching their visa conditions in places such as North America, Europe, and Australia has empowered private actors and corporations who run such places of detention. Multinational corporations such as G4S (the world's largest security company) and Serco (a UK company that manages prisons and immigration detention centers in the United Kingdom and Australia) have become key global players in this immigration detention complex. For transnational corporations, migration control has "become business, big business" both in terms of profiting off individual migrants' desires to move and the state attempts to control such movement. ${ }^{50}$ One prominent effect of the regulation of human mobility through privatization has been the intensification of the carceral state by entrenching the relationship between criminal modes of punishment and immigration law (referred to in migration scholarship as "crimmigration") while also embedding private for-profit corporations into the disciplining of human mobility. ${ }^{51}$

Securitization: The "securitization" of migration through various state forms of control has long been documented and analyzed by scholars. Increasingly, such securitization practices have come to be enacted through a transnational military prism, resulting in the routine (p. 697) deployment of military tactics, personnel, and technology such as drones to patrol state borders and to treat the arrival of unauthorized migrants as a form of transnational organized crime. In recent years, the UN Security Council, too, has authorized states to take military action against people categorized as "people smugglers" in an effort to combat human trafficking. ${ }^{52}$ Such resolutions have facilitated naval patrol operations in the southern central Mediterranean Sea, mandated by decisions of the Council of the European Union. ${ }^{53}$ To date, this has included the boarding and pushback of boats carrying migrants from Libya to southern Europe as well as the destruction of boats that have been or may be used in such "people smuggling operations". While such actions may be seen to be consistent with certain international instruments such as the Protocol against the Smuggling of Migrants by Land, Sea and Air, ${ }^{54}$ these operations have been routinely criticized for their severe breaches of international human rights standards, and 
for the logics of deterrence, containment, and migrant exclusion that such practices enact. ${ }^{55}$ Seen in this vein, practices of transnational migration law are not only about channeling human mobility and seeking to prevent coerced and unfree forms of migration, but conversely are also about authorizing violence against people transgressing state borders and producing states of entrapment and stasis for certain would-be migrants, thus affecting whether people can move in the first place and which migrants are deemed worthy of the protections of human rights law.

To conclude, this brief overview of the regulation of human mobility in a world of plural, and potentially rival, lawmaking authorities has demonstrated the necessity of denaturalizing the state as the privileged "container" through which to understand human mobility. ${ }^{56}$ This task involves understanding how states have come to be constituted and contested in and through their regulation of mobile people. As Joel Quirk and Darshan Vigneswaran have argued:

human mobility has long played a foundational role in determining what states look like as spatial and political entities, how they accumulate power and resources, what types of policies and strategies they pursue, and how they relate to their peers and other political, social, and economic actors. In short, mobility makes states. ${ }^{57}$

Paying attention to the productive and coercive dimensions of regulating human mobility thus allows for questioning the standard legal typologies for framing migration, while also (p. 698) avoiding what Andreas Wemmer and Nina Glick Schiller have called "methodological nationalism." 58 Methodological nationalism in the context of migration law scholarship denotes approaches that take state borders as empirical facts, and fail to interrogate or historicize how migration has fed into processes of state construction, and vice versa. Yet, in developing an understanding of transnational migration law, it is also important not to slip into what I shall term "methodological internationalism" that adopts the "global" as the ideal perspective and that see the international system of states as the "proper" and most optimal way of organizing the world. Such an approach of "methodological internationalism" fails to question how various international institutions and transnational processes, including the increased circulation of capital and goods, act to shore up and entrench this global ordering that has resulted in uneven and racialized production and distribution of wealth, resources, and mobility in the world. After all, to conceive of the world only in terms of formal states is, as Manu Karuka has put it, to "naturalize colonialism." 59 Instead, this chapter suggests that in order to properly comprehend the construction, operation, dynamics, and effects of transnational migration law, we must be attentive to the way how practices of state migration law and regulation intersect with and are sustained by, and in turn sustain, a racialized global ordering of people that enable certain forms of precarity, exploitation, and abuse on the basis of a person's stateattributed "status" within a state's territory. 


\section{Decolonizing Transnational Migration Law}

If we as scholars of "transnational migration law" take such methodological challenges and political critiques seriously, then how might we think about the regulation of human mobility alongside struggles for and projects of decolonization and global justice in our academic work and praxis? How can and should transnational migration law and scholarship respond to the vast and increasing global inequalities in our contemporary world produced through European colonialism and capitalism and maintained-or even exacerbated-through contemporary transnational legal regimes around trade, finance, property, and food, to name but a few examples? How do we understand the global ordering of people in relation to the present-day uneven sharing of wealth, resources, and opportunity, and state attempts to monopolize authority through legal forms of sovereignty?

\section{A. Global Justice, Inequality, and Migration}

Importantly, E. Tendayi Achiume has called on scholars of international law to reconceive of migration as decolonization, where the migration of Third World citizens to First World states "can be understood to enact an important step in...the pursuit of a long overdue geopolitical reordering of benefits of a global order." ${ }^{60}$ Achiume's normative argument is (p. 699) based on demonstrating that citizens of First World and Third World states are "not political strangers" to each other. ${ }^{61}$ Rather, for Achiume, the First and Third Worlds exist in relationships of co-sovereignty and interdependence forged through practices of imperial exploitation and extraction established during the colonial period and continued long after the national liberation of formerly colonized people through forms of contemporary neocolonialism. Such historic interconnections and ongoing injustices mean that First World states therefore should have "no more right to exclude Third World persons than they do their own citizens" and, conversely, citizens of formerly colonized places have a particular right of admission into First World states as a mode of redressing the "colonial advantage" that First World states have gained through colonialism and that is maintained in and through contemporary international (legal) frameworks. Such individual migration, Achiume argues, should be viewed as a legitimate, ethical, and importantly remedial personal response to conditions of neocolonial subordination and as a "matter of corrective distributive justice" on a global scale. Third World migration thus constitutes a valid form of "opportunity-enhancement" behavior for Third World citizens, even if it should not necessarily guarantee them the same rights of citizenship or permanent belonging in First World states as enjoyed by First World citizens. While Achiume realizes that such "postcolonial" migration is a "remarkably personal circumvention of the nation state," nonetheless, for Achiume, it necessitates a fundamental reimagining of sovereignty as a legal concept and holds the possibility of "different construction of the baseline relationship between political-economic migrants and the receiving sovereign." 62

Achiume's intervention in the field of international migration law is timely and much needed, as it reminds us to foreground the power and potential of Third World migration as a matter of material redistribution and global justice. It provides a politically useful legal argument for expanding the prevailing practices of belonging, notions of entitlements, 


\section{Transnational Migration Law: Authority, Contestation, Decolonization}

and spheres of inclusion on the basis of historically produced rights and relations in First World states as a strategy of responding to colonial injustices. It thus makes the historically constructed borders of states the "perennial objects" of accountability. ${ }^{63}$ However, in thinking about the transformative potential of migration in an individualized way (albeit on a mass scale), Achiume's proposal still leaves intact the existing international order of states that rests upon the logic of state borders as both the makers and markers of determining questions of belonging, entitlement, and difference. ${ }^{64}$ This is particularly problematic in the context of settler-colonial states, where the imposition and maintenance of state borders enable the ongoing colonization and appropriation of Indigenous lands, and function as a mechanism for seeking to subordinate prior and ongoing Indigenous forms of sovereignty over land and peoples. ${ }^{65}$

(p. 700) Instead, scholars of decolonization from Indigenous standpoints have argued that decolonization requires a more fundamental unsettling of settler colonialism-in all its epistemological, material, and psychological forms-and a recognition of and reckoning with Indigenous sovereignties and forms of sociality. Writing from Turtle Island (North America), Eve Tuck and K. Wayne Yang, in particular, have argued that decolonization must necessarily also entail a material redistribution of authority over space, people, and resources, and the "repatriation of Indigenous land and life." Indeed, to think of decolonization otherwise would mean that Third World migration to settler colonial states of the "First World" risks intensifying the practices of dispossession and logic of elimination at work in settler colonialism. Tuck and Yang write:

People of color who enter/are brought into the settler colonial nation-state also enter the triad of relations between settler-native-slave. We are referring here to the colonial pathways that are usually described as 'immigration' and how the refugee/immigrant/migrant is invited to be a settler in some scenarios, given the appropriate investments in whiteness, or is made an illegal, criminal presence in other scenarios. ${ }^{66}$

Thinking with this triangulation of settler-native-slave reveals how as a result of paradoxical logics of assimilation and differential practices of racialization, "[s]ome labor becomes settler, while excess labor becomes enslavable, criminal, murderable." Decolonization, for Tuck and Yang, then means the undoing of the settler nation in order to reorient toward Indigenous sovereignties and futurities, through an embrace of an "ethics of incommensurability." ${ }^{67}$ Put more simply, what decolonization requires is clear, through the work of Indigenous theorists; what form decolonization may take and how decolonization will occur in settler colonial states is more open to historical contingency and not knowable in advance.

Recognizing and seeking to address the unequal access to and distribution of citizenship in the world-and its implications for the ability of people to travel in authorized, less dangerous, and less exploitative ways-is only one element then in comprehending global injustice. Migrant struggles for justice must be thought alongside Indigenous practices of self-determination and nationhood in order to adequately and meaningfully account for 
global justice in the present. How we as migration law scholars narrate transnational migration law must be engaged in such endeavors. This means taking seriously past and present (p. 701) Indigenous mobility practices and Indigenous legal techniques for authorizing and making lawful certain forms of mobility. ${ }^{68}$

\section{B. Telling "Counterstories" as an Academic Praxis}

Storytelling is political. Depending on the standpoint of the narrator, the mode of narration and the geopolitical context in which stories are told and received, stories can authorize and reproduce dominant power structures, or intervene in and transform global hierarchies, social imaginaries, and collective movements for social change. ${ }^{69}$ What stories we tell, pay attention to and foreground as scholars of transnational migration law reveals a great deal about how we conceive of, locate, and relate to power and authority, in particular whose laws we recognize and who we deem to be an actor of transnational migration lawmaking. For many Indigenous scholars, stories hold law, and acts of storytelling can function as acts of legal obligation, transmission, and place-making. ${ }^{70}$ For nonIndigenous scholars, like myself, foregrounding "counterstories" of transnational migration lawmaking to that of the state or market may function as a form of academic solidarity and commitment to projects of anti-racism and decolonization. ${ }^{71}$ In this final section, I suggest that stories can have a powerful role to play in the necessary work of undoing colonial borders and state practices of bordering in the present, provided they are told and received within an ethical framework that emphasizes the narrator's positionality and an ethics of nonappropriation, permission-seeking, and respect. ${ }^{72}$

One possible orientation that such stories can take is to reveal the connections between state treatment of Indigenous peoples and racialized migrants in settler colonial contexts. This may include stories of how both Indigenous peoples and racialized migrants are made exceptional in state law, and subject to similar techniques of state documentation, intrusion, and incarceration. Analyzing the use of the plenary power in the United States, Susan Bibler Coutin, Justin Richland, and Véronique Fortin, for example, have mobilized personal stories of migrant and Indigenous peoples' encounters with the law to show how such state (p. 702) techniques of claiming jurisdiction 'function of granting 'fullness' to the United States while at the same time requiring certain populations to routinely claim exceptionality."73 In the Australian context, the Deathscapes project, led by Suvendrini Perera and Joseph Pugliese, has collated stories of state-perpetrated abuses and custodial deaths of Indigenous people and migrants as a way of documenting, mapping, and ultimately resisting contemporary forms of racialized violence across settler colonial locations. Focusing on a variety of sites, including "police cells, prisons and immigration detention centres," these stories seek "not to collapse the differences between racialized groups, or to ignore the presence of other racialized populations in these states, but to address some of the shared strategies, policies, practices and rationales of state violence deployed in the management of these separate categories." 74 


\section{Transnational Migration Law: Authority, Contestation, Decolonization}

Another orientation that such stories can and do take is to draw attention to the effect of colonial states borders in dividing Indigenous nations and obscuring Indigenous sovereignties. For example, Theresa McCarthy has written about how the Six Nations of the Haudenosaunee Confederacy have historically negotiated the state-imposed border controls that act to divide and marginalize their political authority and communal life. She writes that while "the U.S.-Canada 'border' is a settler construct that is foreign and without meaning to Haudenosaunee cosmology, it has had very real, substantive implications for the social and political coherence of Haudenosaunee people over time." Nonetheless, despite these state borders, McCarthy shows how the "inherent sovereignty of Haudenosaunee has been continually articulated as the right to determine citizenship, leadership, and freedom of movement within territorial homelands." 75 This means that state borders have never fully been able to remove Indigenous control over what Amar Bhatia has called Indigenous "re-peopling" powers (that is, Indigenous authority over acts of procreation, marriage, adoption, citizenship, and immigration), despite considerable endeavors to do so. ${ }^{76}$ For example, a recent Australian High Court case has challenged the Australian government's constitutional powers to deport people who are members of Indigenous nations in Australia but who do not have Australian citizenship (people who in the legal terminology of the settler colonial state are deemed "Indigenous noncitizens"). ${ }^{77}$ With the majority of the High Court ultimately holding that Aboriginal Australians occupy a "unique or sui generis position...such that they are not aliens" under the Australian Constitution, the decision (p. 703) impels a reconfiguration of the relationship between the Australian settler colonial state's deportation powers and the operation of Indigenous sovereignty and the right to self-determination. As Bhatia writes, "viewing Indigenous nations as self-determining nations means recognizing their inherent rights and power to reproduce their societies through birth and immigration," even if settler colonial states through strategies of elimination seek to submerge and ultimately eliminate such Indigenous forms of authority. ${ }^{78}$ Similarly, Louise Boon-Kuo has argued that the current Australian settler colonial state's use of migration law in attempts to deport Indigenous people deemed noncitizens must be understood within a longer colonial history of dispossessing Indigenous peoples, separating Indigenous families, and deporting racialized noncitizens: all practices tied to a project of making Australia a "white" nation that was inaugurated upon the foundational and continued denial of Indigenous sovereignty. For Boon-Kuo, such practices of "white possessive sovereignty" remind us of the need for migration scholarship to "engage with the continued existence and state denial of First Nation sovereignties." 79

A third possible orientation for such stories of transnational migration law can be to foreground Indigenous-to-Indigenous practices of law. Here, for example, the stories of Indigenous uses of the passport as potentially disruptive anticolonial legal objects can make visible the ongoing practices of sovereignty and recognition of Indigenous nations in the present as well as the failure on the part of settler colonial states to "fully monopolise" the "legitimate means of movement." Audra Simpson, for example, has theorized how Indigenous practices of sovereignty that utilize the passport form, rather than seeking to replicate European or settler colonial border practices, instead exercise a "funda- 
mentally interrupted and interruptive capacity" to the existent settler colonial state and international ordering of political authority. ${ }^{80}$ Similarly, Joseph Pugliese has suggested in the Australian context that Indigenous acts of issuing and using Aboriginal passports function as "counter-discursive resignification of the very technology-the passport-deployed by the settler-colonial Australian state in order to consolidate and reproduce the ongoing usurpation of Indigenous sovereignty." 81 In doing so, Pugliese argues, Aboriginal uses of the passport act to "mark Aboriginal people's unceded and unextinguished sovereignty over Country and their right to offer welcome and hospitality within their own lands." 82 Foregrounding such stories in accounts of transnational migration law, then, heeds plural and rival forms of authority over land and people, and works against the dominant logics of settler colonial formations that would seek to eradicate and deny Indigenous sovereignties, nationhoods, and futures.

\section{(p. 704) IV. Conclusion}

This chapter has provided an account of transnational migration law as an empirical, methodological, and normative inquiry. If transnational migration law is the object of investigation of this chapter, I have argued that it is not an already-present phenomenon or readily given object of inquiry. Rather, it is constructed through deploying the terminology of the "transnational" in relation to a politics of recognition. What does or should count as transnational migration law? Who is recognized as a lawful authority over human mobility? And what are the implications of this constitutive boundary-drawing exercise, in delimiting what is, and what is not, transnational migration law? At stake in such an exercise is more than merely the task of accurate description or reconstruction. It is rather the possibility of enabling more just coexistences between plural forms of law and the task of thinking through what a transnational migration law might look like that recognizes the necessity of thinking migrant justice within and beyond the settler colonial state.

To conclude, I want to return to another story about passports as documents that can attest to the regulation of human mobility in a world of plural authorities and that opens up the importance of decolonizing approaches to "transnational migration law." In 2013, a Freedom Solidarity Flotilla consisting of a delegation of Aboriginal Elders and West Papuan freedom activists sailed from Naarm/Melbourne to Manokwari in support of the independence struggle of the West Papuan people and to denounce the Australian government's support for Indonesia's military interventions. Traveling on his Original Nations Passport as part of the delegation, Gunai man Robbie Thorpe articulated the importance of Indigenous passports as a form of inter-Indigenous sovereign relations and lawmaking, including in the context of human mobility:

Aboriginal Passports represent a Global Safe Travel document; Indigenous people of Australia have never invaded or attacked another country, Aboriginal people represent peace and these passports represent a connection between Indigenous people around the world who have suffered at the hands of colonisation....Who[se] 
borders are these anyway? Why should we require the white man's documents to travel to West Papua? Our lands were once connected, our cultures entwined for thousands of years, we don't need authority from Australia or Indonesia to do as we have always done. Aboriginal Passports are a real statement about our land, our identity, our lore. Australia and Indonesia can live the lie, but we the Indigenous people don't subscribe to that. ${ }^{83}$

Scholars of transnational migration law thus have a responsibility to recognize and analyze both the multitude of practices, sites, actors, and forms of migration control (in all their complexity, violence, and exclusions) and to foreground the varied rival forms of authority over the regulation of both space and mobile people that present a challenge to the current international ordering and maintenance of states, an international system that is the ongoing product of imperialism and settler colonial formations as well as struggles for decolonisation.

\section{Selective Bibliography}

Achiume, E. Tendayi. “Migration as Decolonisation.” Stanford Law Review 71 (2019): 1509-1574.

Amaya-Castro, Juan. “'In Its Majestic Inequality': Migration Control and Differentiated Citizenship." In The Transformation of Citizenship, vol. 2, edited by Jürgen Mackert and Bryan S. Turner, 84-100. Abingdon: Routledge, 2017.

Bacon, David. Illegal People: How Globalization Creates Migration and Criminalizes Immigrants. Boston: Beacon Press, 2009.

Bhatia, Amar. "'In a Settled Country, Everyone Must Eat': Four Questions about Transnational Private Regulation, Migration, and Migrant Work." German Law Journal 13, no. 12 (2012): 1282-1295.

Bhatia, Amar. "Re-peopling in a Settler-Colonial Context: The Intersection of Indigenous Laws of Adoption with Canadian Immigration Law." AlterNative 14, no. 4 (2018): 343353.

Bibler Coutin, Susan, Richland, Justin and Fortin, Véronique. "Routine Exceptionality: The Plenary Power Doctrine, Immigrants, and the Indigenous Under U.S. Law." UC Irvine Law Review 4 (2014): 97-120.

Boon-Kuo, Louise. "'Race', Crimmigration and the Deportation of Aboriginal Non-Citizens." In Crimmigration in Australia: Law, Politics, and Society, edited by Peter Billings. Singapore: Springer, (2019): 39-62.

Burrows, John. Freedom and Indigenous Constitutionalism. Toronto: University of Toronto Press, 2016. 
Dauvergne, Catherine. Making People Illegal: What Globalization Means for Migration and Law. Cambridge: Cambridge University Press, 2008.

Dehm, Sara. "Passport." In International Law's Objects, edited by Jessie Hohmann and Daniel Joyce, 342-356. Oxford: Oxford University Press, 2018.

Dembour, Marie-Bénédicte. When Humans Become Migrants: Study of the European Court of Human Rights with an Inter-American Counterpoint. Oxford: Oxford University Press, 2015.

Gammeltoft-Hansen, Thomas and Nyberg Sorensen, Ninna. The Migration Industry and the Commercialization of International Migration. Abingdon: Routledge, 2013.

Geiger, Martin and Pécoud, Antoine (eds.). Disciplining the Transnational Mobility of People. Basingstoke: Palgrave Macmillan, 2013.

Simpson, Audra. Mohawk Interruptus: Political Life Across the Borders of Settler States. Durham: Duke University Press, 2014.

Smith, Adrian A. "Migration, Development and Security within Racialised Global Capitalism: Refusing the Balance Game." Third World Quarterly 37, no. 11 (2016): 2119-2138.

Stephen, Lynn. Transborder Lives: Indigenous Oaxacans in Mexico, California, and Oregon. Durham: Duke University Press, 2007.

Thomas, Chantal. "Transnational Migration, Globalization, and Governance: Theorizing a Crisis." In Oxford Handbook of the Theory of International Law, edited by Anne Orford and Florian Hoffmann, 882-921. Oxford: Oxford University Press, 2016.

Vigneswaran, Darshan and Quirk, Joel (eds.). Mobility Makes States: Migration and Power in Africa. Philadelphia: University of Pennsylvania Press, 2015.

Wimmer, Andreas and Glick Schiller, Nina. "Methodological Nationalism and Beyond: Nation-State Building, Migration and the Social Sciences." Global Networks 2, no. 4 (2002):

301-334. (p. 706)

\section{Notes:}

(*) This chapter was written on the lands of the Gadigal people of the Eora nation. I am grateful to Amar Bhatia, ManojDias- Abey, Ben Silverstein, and Peer Zumbansen for their scholarly generosity, editorial suggestions, helpful references, and good humor.

( $\left.{ }^{1}\right)$ Sam Laskaris, "Passports Rejected: Haudenosaunee Women’s LAX Withdraws from World Championships," Indian Country Today Media Network, July 20, 2015, http:// indiancountrytodaymedianetwork.com/2015/07/20/passports-rejected-haudenosauneewomens-lax-withdraws-world-championships-161139; see also Sara Dehm, "Passport," in 
International Law's Objects, eds. Jessie Hohmann and Daniel Joyce (Oxford: Oxford University Press, 2018), 342-356.

$\left({ }^{2}\right)$ Kaya Burgess, "Native American Lacrosse Team Allowed to Come to Britain on Haudenosaunee Passports," The Times (UK), July 22, 2017, https://www.thetimes.co.uk/article/native-american-lacrosse-team-allowed-to-come-to-britain-on-haudenosaunee-passports-qspzt6jsc.

$\left({ }^{3}\right)$ Celia Balf, "A Team of Native American Players Is Making History at the 2017 Lacrosse Women's World Cup," Excelle Sport, July 19, 2017, http://www.excellesports.com/news/ lacrosse-haudenosaunee-fil-rathbones-world-cup. On the history of Haudenosaunee lacrosse teams' use of the passport, see Allan Downey, The Creator's Game: Lacrosse, Identity, and Indigenous Nationhood (Vancouver: UBC Press, 2018).

$\left.{ }^{4}\right)$ On the concept of rival authorities, see Shaun McVeigh and Sundhya Pahuja, "Rival Jurisdictions: The Promise and Loss of Sovereignty," in After Sovereignty: On the Question of Political Beginnings, eds. Charles Barbour and George Pavlich (Abingdon: Routledge, 2009), 97-114; Sundhya Pahuja, "Laws of Encounter: A Jurisdictional Account of International Law," London Review of International Law 1, no. 1 (2013): 63-98.

$\left({ }^{5}\right)$ In making this argument, I am indebted to Peer Zumbansen's theorizing of the "transnational" as a methodology: see Peer Zumbansen, "Transnational Legal Pluralism," Transnational Legal Theory 1, no. 2 (2010): 141-189.

$\left({ }^{6}\right)$ John Torpey, The Invention of the Passport: Surveillance, Citizenship and the State (Cambridge: Cambridge University Press, 2000), 5.

$\left({ }^{7}\right)$ See especially Amar Bhatia, "We Are All Here to Stay? Indigeneity, Migration, and 'Decolonizing' the Treaty Right to Be Here," Windsor Yearbook of Access to Justice 31, no. 2 (2013): 39-64; Amar Bhatia, “'In a Settled Country, Everyone Must Eat': Four Questions about Transnational Private Regulation, Migration, and Migrant Work," German Law Journal 13, no. 12 (2012): 1282-1295.

$\left(^{8}\right)$ Zygmunt Bauman, Globalization: The Human Consequence (New York: Polity Press, 1998), 88; Anthony Richmond, Global Apartheid: Refugees, Racism, and the New World Order (Oxford: Oxford University Press, 1994); Nandita Sharma, "Global Apartheid and Nation-Statehood: Instituting Border Regimes," in Nationalism and Global Solidarities: Alternative Projections to Neoliberal Globalisation, eds. James Goodman and Paul James (Abingdon: Routledge, 2006), 71-90.

$\left({ }^{9}\right)$ See Jessup's foundational definition of transnational law as "all law which regulates actions or events that transcend national frontiers" and consists of a mix between public and private forms of regulation: Philip Jessup, Transnational Law (New Haven: Yale University Press, 1956), 2; see also Carrie Menkel-Meadow, "Why and How to Study 'Transnational' Law,” UC Irvine Law Review 1, no. 1 (2011): 97-128.

(10) See Zumbansen, supra note 5. 
(11) Juan Amaya-Castro, "'In Its Majestic Inequality': Migration Control and Differentiated Citizenship," in The Transformation of Citizenship, vol. 2, eds. Jürgen Mackert and Bryan S. Turner (Abingdon: Routledge, 2017), 84-100.

(12) Catherine Dauvergne, Making People Illegal: What Globalization Means for Migration and Law (Cambridge: Cambridge University Press, 2008), 2.

(13) This approach to law owes much to, yet is distinct from other accounts of law in "transnational law" or "legal pluralism" scholarship. In the former tradition, e.g., a prevailing understanding of transnational law is the "study of legal phenomena, including lawmaking processes, rules, and legal institutions, that affect or have the power to affect behaviors beyond a single state border" (Menkel-Meadow, "Why and How to Study 'Transnational' Law," supra note 9, at 104). Here a guiding question is one of regulatory effectiveness, rather than the lawful characterisation or status of the enacting body. In the legal pluralism tradition, in contrast, law has been framed as and through multiplicity, uncovering multiple overlapping jurisdictions, affiliations, legal systems, and social orders (see, e.g., Eve Darian-Smith, Laws and Societies in Global Contexts: Contemporary Approaches (Cambridge: Cambridge University Press, 2013)).

(14) Shaunnagh Dorsett and Shaun McVeigh, Jurisdiction (Abingdon: Routledge, 2012); Pahuja, "The Law of Encounters," supra note 4.

(15) Dauvergne, supra note 12. See also David Bacon, Illegal People: How Globalization Creates Migration and Criminalizes Immigrants (Boston: Beacon Press, 2009).

${ }^{(16)}$ Making Migration Work for All: Report of the Secretary-General, UN Doc. A/72/643, December 12, 2017, 2.

(17) Simon Behrman, "Refugees and Crises of Law," Patterns of Prejudice 52, nos. 2-3 (2018): 107-120. Moreover, as many scholars have noted, that such "migration crisis" are in fact produced through forms of law and regulation. See, e.g., Chantal Thomas, “Transnational Migration, Globalization, and Governance: Theorizing a Crisis," in Oxford Handbook of the Theory of International Law, eds. Anne Orford and Florian Hoffmann (Oxford: Oxford University Press, 2016), 882-921.

(18) Zygmunt Bauman, Strangers at Our Door (Malden, MA: Polity, 2016).

${ }^{(19)}$ Here some scholars have productively unpack the concept of the border, or "bordering" as a way of analyzing the proliferation and intensification processes of differentiation and containment: see, e.g., Sandro Mezzadra and Brett Nielson, Border as Method, or, the Multiplication of Labor (Durham: Duke University Press, 2013); Gargi Bhattacharyya, Rethinking Racial Capitalism: Questions of Reproduction and Survival (London: Rowman \& Littlefield, 2018). On the global production of precarious working conditions for migrants, see Louise Waite et. al. eds., Vulnerability, Exploitation and Migrants: Insecure Work in a Globalised Economy (Basingstoke: Palgrave Macmillan, 2015). 
$\left({ }^{20}\right)$ See generally Dimitris Papadopoulos, Niamh Stephenson, and Vassilis Tsianos, Escape Routes: Control and Subversion in the Twenty-First Century (London: Pluto Press, 2008).

(21) See, e.g., Koen Leurs, "Communication Rights from the Margins: Politicising Young Refugees' Smartphone Pocket Archives," International Communication Gazette 79, nos. 6-7 (2017): 674-698; Simona Zavratnik and Sanja Cukut Krilić, “Digital Routes, 'Digital Migrants': From Empowerment to Control over Refugees' Digital Footprints,” Družboslovne Razprave 34, no. 89 (2018): 143-163.

(22) Stefan Rother, "Angry Birds of Passage: Migrant Rights Networks and Counter-Hegemonic Resistance to Global Migration Discourses," Globalizations 15, no. 6 (2018): 854$869,855$.

(23) Stefan Rother, "A Tale of Two Tactics: Civil Society and Competing Visions of Global Migration Governance from Below," in Disciplining the Transnational Mobility of People, eds. Martin Geiger and Antoine Pécoud (Basingstoke: Palgrave Macmillan, 2013), 41-62.

(24) CIW, "Fair Food Program," https://www.fairfoodprogram.org. For an insightful history and analysis of the CIW's approach, see Manoj Dias-Abey, "Justice on Our Fields: Can 'AltLabor' Organizations Improve Migrant Farm Workers' Conditions?," Harvard Civil RightsCivil Liberties Law Review 53 (2018): 167-211.

$\left({ }^{25}\right)$ See, e.g., Dehm, supra note 1, at 349.

$\left({ }^{26}\right)$ Fiona B. Adamson and Gerasimos Tsourapas, "The Migration State in the Global South: Nationalizing, Developmental, and Neoliberal Models of Migration Management," International Migration Review 54, no. 3 (2020): 853-882.

(27) Discovery Health v. CCMA, [2008] ZALC 24 (South Africa).

$\left.{ }^{28}\right)$ Laura Griffin, "When Borders Fail: 'Illegal', Invisible Labour Migration and Basotho Domestic Workers in South Africa," in Constructing and Imagining Labour Migration Perspectives of Control from Five Continents, eds. Elizabeth Guild and Sandu Mantu (Farnham: Ashgate, 2011), 15-38. See also Laura Griffin, "Unravelling Rights: 'Illegal' Migrant Domestic Workers in South Africa," South African Review of Sociology 42, no. 2 (2011): 83-101.

$\left({ }^{29}\right)$ Decision No. 1773/17, [2017] ONWSIAT 2962, online (http://www.wsiat.on.ca/Decisions/2017/1773\%2017.pdf) (Canada).

( $\left.{ }^{30}\right)$ See also Adrian A. Smith, "Migration, Development and Security within Racialised Global Capitalism: Refusing the Balance Game," Third World Quarterly 37, no. 11 (2016): 2119-2138.

${ }^{31}$ ) This expression is from Torpey, supra note 6 , at 5. 
(32) See Chantal Thomas, "Convergences and Divergences in International Legal Norms on Migrant Labor," Comparative Labor Law and Policy Journal 32, no. 2 (2011): 405-441.

(33) African Commission of Human and Peoples' Rights, Communication No. 159/96 (November 11, 1997), para. 20.

( $\left.{ }^{34}\right)$ Juridical Condition and Rights of Undocumented Migrants (2003), Advisory Opinion OC-18/03, Inter-Am Ct. HR (Ser. A) No. 18, http://www.corteidh.or.cr/docs/opiniones/ seriea_18_ing.pdf.

${ }^{(35)}$ Undocumented Workers: United States of America (2016), Inter-Am Comm HR, Merits Report No. 50/16, Case 12.834.

( $\left.{ }^{36}\right)$ See Hoffman Plastic Compounds, Inc. v. National Labor Relations Board, 535 US 137 (2002) (Hoffman).

$\left({ }^{37}\right)$ United States Department of State, Digest of United States Practice in International Law, ed. CarrieLyn D. Guymon (2016), 328.

(38) Marie-Bénédicte Dembour, When Humans Become Migrants: Study of the European Court of Human Rights with an Inter-American Counterpoint (Oxford: Oxford University Press, 2015), 302.

( $\left.{ }^{39}\right)$ James Cavallaro and Stephanie Brewer, "Reevaluating Regional Human Rights Litigation in the Twenty-First Century: The Case of the Inter-American Court," American Journal of International Law 102, no. 4 (2008): 768-827, 823.

$\left({ }^{40}\right)$ African Union, The Migration Policy Framework for Africa, Doc. No. EX.CL/276 (IX), June 2006, online (https://au.int/sites/default/files/pages/32899-

file-1._au_migration_policy_framework_for_africa.pdf).

(41) Sandra Lavenex, "Regional Migration Governance: Building Block of Global Initiatives?," Journal of Ethnic and Migration Studies 45, no. 8 (2019): 1275-1293.

$\left({ }^{42}\right)$ On the use of this terminology, see, e.g., Christiane Kuptsch ed., Merchants of Labour (Geneva: International Institute for Labour Studies, 2006); Philip Martin, Merchants of Labor: Recruiters and International Labor Migration (Oxford: Oxford University Press, 2017).

(43) Bassina Farbenblum and Justine Nolan, "The Business of Migrant Worker Recruitment: Who Has the Responsibility and Leverage to Protect Rights?," Texas International Law Journal 52, no. 1 (2017): 1-44.

$\left({ }^{44}\right)$ Sophie Scholten, The Privatisation of Immigration Control through Carrier Sanctions (Leiden: Brill Nijhoff, 2015); Tendayi Bloom, "The Business of Migration Control: Delegating Migration Control Functions to Private Actors," Global Policy 6, no. 2 (2015): 151-157. 
$\left({ }^{45}\right)$ The Dhaka Principles are based on international human rights instruments and ILO core standards. They have since been endorsed by the International Trade Union Confederation and the International Confederation of Private Employment Agencies (CIETT). On the "governance deficit" in the global recruitment of labour, or what Jennifer Gordon terms the "human supply chain," see Jennifer Gordon, "Regulating the Human Supply Chain," Iowa Law Review 102, no. 2 (2017): 445-504.

(46) See the dynamic accounts of First Nations law developed in different settler colonial contexts: e.g., in Australia by Irene Watson, Aboriginal Peoples, Colonialism and International Law: Raw Law (Abingdon: Routledge, 2015); and in Canada by John Burrows, Law's Indigenous Ethics (Toronto: University of Toronto Press, 2019).

$\left({ }^{47}\right)$ See, e.g., Shiri Pasternak, "Jurisdiction and Settler Colonialism: Where Do Laws Meet?" Canadian Journal of Law and Society 29, no. 2 (2014): 145-161.

(48) Stephan Scheel, Autonomy of Migration?: Appropriating Mobility within Biometric Border Regimes (Abingdon: Routledge, 2019). While many states such as those in the European Union have implemented biometric identification systems at border points, more recently, Australian airport and immigration officials have announced a new trial that will scan a traveler's face, without the need to present their passport when passing through Australian immigration controls. Here, the traveler's body becomes the space onto which regulation through technology is projected and authorized forms of movement are coded.

$\left({ }^{49}\right)$ See Farbenblum and Nolan, supra note 42 . Other states such as the Philippines have used social media as a way of holding recruiters and employers more publicly accountable to migrant workers and their families. See also Bassina Farbenblum, Laurie Berg and Angela Kintominas, "Transformative Technology for Migrant Workers: Opportunities, Challenges, and Risks" (New York: Open Foundation, 2018).

$\left({ }^{50}\right)$ Thomas Gammeltoft-Hansen and Ninna Nyberg Sorensen, The Migration Industry and the Commercialization of International Migration (Abingdon: Routledge, 2013), 2. See also Siobhán McGuirk and Adrienne Pine eds., Asylum for Sale: Profit and Protest in the Migration Industry (Oakland: PM Press, 2020).

( $\left.{ }^{51}\right)$ On "crimmigration," see, e.g., Juliet Stumpf, "The Crimmigration Crisis: Immigrants, Crime, and Sovereign Power," American University Law Review 56, no. 2 (2007): 367420; Katja Franko Aas and Mary Bosworth eds., The Borders of Punishment: Migration, Citizenship, and Social Exclusion (Oxford: Oxford University Press, 2013).

(52) See UN Doc. S/RES/2240 (2015) and UN Doc. S/RES/2380 (2017).

(53) EC, Council Decision (CFSP) 2015/778 of 18 May 2015 on a European Union military operation in Southern Central Mediterranean (EUNAVFOR), [2015] OJ, L 122. See Glenda Garelli and Martina Tazzioli, "The Biopolitical Warfare on Migrants: EU Naval Force and NATO Operations of Migration Government in the Mediterranean," Critical Military Studies 4 , no. 2 (2018): 181-200. 
$\left({ }^{54}\right)$ Protocol against the Smuggling of Migrants by Land, Sea and Air supplementing the UN Convention against Transnational Organized Crime, November 15, 2000, 2241 UNTS 507 (entered into force January 28, 2004).

(55) Jørgen Carling and María Hernández-Carretero, "Protecting Europe and Protecting Migrants? Strategies for Managing Unauthorised Migration from Africa," The British Journal of Politics and International Relations 13, no. 1 (2011): 42-58.

$\left({ }^{56}\right)$ Andreas Wimmer and Nina Glick Schiller, "Methodological Nationalism and Beyond: Nation-State Building, Migration and the Social Sciences," Global Networks 2, no. 4 (2002): 301-334.

$\left({ }^{57}\right)$ Joel Quirk and Darshan Vigneswaran, "Mobility Makes States," in Mobility Makes States: Migration and Power in Africa, eds. Darshan Vigneswaran and Joel Quirk (Philadelphia: University of Pennsylvania Press, 2015), 1-34, 2.

(58) Wimmer and Glick Schiller, supra note 56.

( $\left.{ }^{59}\right)$ Manu Karuka, Empire’s Tracks (Oakland: University of California Press, 2019), xii.

$\left({ }^{60}\right)$ E. Tendayi Achiume, "Reimagining International Law for Global Migration: Migration as Decolonization?," AJIL Unbound 111 (2017): 142-146, 145.

(61) E. Tendayi Achiume, "Migration as Decolonisation," Stanford Law Review 71 (2019): 1509-1574.

$\left({ }^{62}\right)$ Ibid.

(63) Sara Dehm, “'Accusing Europe': Articulations of Migrant Justice and a Popular International Law," in Peoples' Tribunals and International Law, eds. Andrew Byrnes and Gabrielle Simm (Cambridge: Cambridge University Press, 2018), 157-81, 180, quoting Craig Borowiak, Accountability and Democracy: The Pitfalls and Promise of Popular Control (Oxford: Oxford University Press, 2011), 9.

(64) Recall Étienne Balibar's words of how contemporary state borders function as sites for rendering earlier colonial practices of racial differentiation and exclusion internal to the category of national citizenship. Étienne Balibar, Politics and the Other Scene (London: Verso, 2002), 85.

$\left({ }^{65}\right)$ Achiume does recognize the particular place of Indigenous peoples in settler-colonial states that are "founded on the colonial extermination and subordination of sovereign indigenous peoples"; however, she suggests that her general argument about Third World inclusion and equality through First World citizenship "may be moot" in relation to Indigenous peoples who may already hold formal citizenship of settler-colonial states of the Global North, even if this formal status may still enable "fundamental substantive inequality" (supra note 61, at 1563). Achiume writes: "Of course, the subordinate status of many Fourth World peoples who are formal First World citizens speaks to the fundamental substantive inequality that is compatible with formal citizenship status. My point here 
is simply that formal citizenship status is preferable to undocumented status" (supra note 61 , at 1563).

As a result, in positioning the settler-colonial state as the proper and principal authority for granting recognition and inclusion, this is a form of decolonial politics that risks taking place at the expense of Indigenous political authority, legal orderings, and peoples.

(66) Eve Tuck and K. Wayne Yang, “Decolonization Is Not a Metaphor," Decolonization: Indigeneity, Education \& Society 1, no. 1 (2012): 1-40, 17.

$\left({ }^{67}\right)$ Ibid.

(68) See, e.g., Lynn Stephen, Transborder Lives: Indigenous Oaxacans in Mexico, California, and Oregon (Durham: Duke University Press, 2007); John Burrows, Freedom and Indigenous Constitutionalism (Toronto: University of Toronto Press, 2016), especially 1949. For recent historical scholarship on Indigenous mobilities, see Lynette Russell, Roving Mariners: Australian Aboriginal Whalers and Sealers in the Southern Oceans, 1790-1870 (Albany: SUNY Press, 2012); Fiona Paisley, The Lone Protestor: A M Fernando in Australia and Europe (Canberra: Aboriginal Studies Press, 2012); Jane Carey and Jane Lydon eds., Indigenous Networks: Mobility, Connections and Exchange (New York: Routledge, 2014); Rachel Standfield ed., Indigenous Mobilities: Across and Beyond the Antipodes (Acton: ANU Press and Aboriginal History, 2018).

(69) Sujatha Fernandes, Curated Stories: The Uses and Misuses of Storytelling (Oxford: Oxford University Press, 2017).

$\left({ }^{70}\right)$ See, e.g., Christine Black, "Maturing Australia through Australian Aboriginal Narrative Law," South Atlantic Quarterly 110, no. 2 (2011): 347-362; Sweeney Windchief and Kenneth E. Ryan, "The Sharing of Indigenous Knowledge through Academic Means by Implementing Self-Reflection and Story," AlterNative 15, no. 1 (2019): 82-89.

( $\left.{ }^{71}\right)$ On the politics and anti-racist potential of "counterstories," see, e.g., Tara J. Yosso, Critical Race Counterstories along the Chicana/Chicano Educational Pipeline (New York: Routledge, 2006).

( $\left.{ }^{72}\right)$ See, e.g., Clare Land, Decolonising Solidarity (London: Zed Books, 2015).

(73) See Susan Bibler Coutin, Justin Richland, and Véronique Fortin, "Routine Exceptionality: The Plenary Power Doctrine, Immigrants, and the Indigenous Under U.S. Law," UC Irvine Law Review 4 (2014): 97-120. See also Leti Volpp, “The Indigenous as Alien," UC Irvine Law Review 5 (2015): 289-325.

( $\left.{ }^{74}\right)$ "Deathscapes: Mapping Race and Violence in Settler States," https:// www.deathscapes.org/about-project.

( $\left.{ }^{75}\right)$ See, e.g., Theresa McCarthy, In Divided Unity: Haudenosaunee Reclamation at Grand River (Tucson: University of Arizona Press, 2016), 210; Michel Hogue, Metis and the Medicine Line: Creating a Border and Dividing a People (Chapel Hill: University of North Car- 
olina Press, 2015); Audra Simpson, Mohawk Interruptus: Political Life Across the Borders of Settler States (Durham: Duke University Press, 2014).

( $\left.{ }^{76}\right)$ Amar Bhatia, "Re-peopling in a Settler-Colonial Context: The Intersection of Indigenous Laws of Adoption with Canadian Immigration Law," AlterNative 14, no. 4 (2018): 343-353.

$\left({ }^{77}\right)$ Love v. Commonwealth of Australia; Thoms v. Commonwealth of Australia [2020] HCA 3 (11 February 2020)

$\left.{ }^{78}\right)$ Bhatia, supra note 74, at 348. On settler colonialism's logic of elimination, see Patrick Wolfe, "Settler-Colonialism and the Elimination of the Native," Journal of Genocide Research 8, no. 4 (2006): 387-409.

( $\left.{ }^{79}\right)$ Louise Boon-Kuo, "'Race', Crimmigration and the Deportation of Aboriginal Non-Citizens," in Crimmigration in Australia: Law, Politics, and Society, ed. Peter Billings (Singapore: Springer, 2019), quoting Aileen Moreton-Robinson, The White Possessive: Property, Power, and Indigenous Sovereignty (Minneapolis: University of Minnesota Press, 2015): 39-62.

(80) Simpson, supra note 75.

$\left({ }^{81}\right)$ Joseph Pugliese, “Geopolitics of Aboriginal Sovereignty: Colonial Law as 'a Species of Excess of Its Own Authority,' Aboriginal Passport Ceremonies and Asylum Seekers," Law Text Culture 19, no. 1 (2015): 84-115, 86.

$\left.{ }^{82}\right)$ Ibid., 95.

(83) “Aboriginal Passports Grant Authority for Cultural Reunion," National United Government, https://nationalunitygovernment.org/content/aboriginal-passports-grant-authoritycultural-reunion.

\section{Sara Dehm}

Dr. Sara Dehm is Lecturer in International Law at the Faculty of Law, University of Technology Sydney, Australia. She researches in the areas of public international law, international migration and refugee law, and the history and theory of international law and institutions. Her work engages the interrelationship between global inequalities, imperialism, decolonization, and struggles for migrant justice. 